\title{
SWOT Analysis and Its Implementation Strategies in Educational Management
}

\author{
Yoseph Belen Keban $^{1^{*}} \quad$ Syaiful Arifin ${ }^{2} \quad$ Rudi Wahyono ${ }^{2}$ \\ 1.Postgraduate of Program Management, University of Merdeka Malang, Indonesia \\ 2.Faculty Economic and Business, University of Merdeka Malang, Indonesia
}

\begin{abstract}
This study had the following purposes: (1) to analyze, (2) to describe SWOT, and (3) to formulate the appropriate SWOT's implementation strategy of educational management at Integrated Vocational School Turen, Malang. The method used in this study was so-called mixed method or a combined method of quantitative-qualitative research. The sample used five (5) people as key informants. The analysis technique utilized was the SWOT analysis. The results of the study showed that there were four obtained strategies' formulas, namely as: SO (strength-opportunity strategy), WO (weaknesses-opportunity strategy), ST (strength-threat strategy), and WT (weaknesses threats strategy). Based on the results of the SWOT analysis, the appropriate implementation strategy in the educational management in Vocational Schools was "aggressive strategy". This signified that the educational institution should support an aggressive growth policy (Growth oriented strategy) with a strength-opportunity strategy approach.

Keywords: SWOT analysis, strategy implementation, educational management
\end{abstract}

DOI: $10.7176 / \mathrm{JEP} / 10-12-10$

Publication date: April $30^{\text {th }} 2019$

\section{Introduction}

Global life is a life which is full of various challenges. Along with the development of digital technology era that now dominates all areas of life, humans are required to be able to survive and to be able to compete. This phenomenon can also be applied apply to non-profit organizations such as education. Today the rivalry between educational institutions is increasingly competitive and tensed. It is shown clearly such as being competitive in improving the quality of education, infrastructure development, getting new students, educators, and various other competitions.

Schools as formal education institutions should carry out their duties properly. Their task is to manifest the educational objectives that have been formulated by the Indonesian Government. The objectives are stated in the Preamble of the 1945 Constitution. It concerns on the efforts of educating the nation. Thus, a good management is needed. Good management certainly requires a strategy in order to sell additional value from educational institutions. The strategy in improving the quality of education is inseparable from the management of quality or quality improvement at school. In Strategic Management, strategies are defined as various ways to achieve goals or "ways to achieve ends" (Solihin, 2012). While the management terminology in English is "to manage" which means regulating, managing, managing, and implementing, as well as supervising (Saebani, 2016). Strategies in educational management can be obtained or known through the help of SWOT analysis.

SWOT analysis is a tool which is utilized during an analysis to examine the internal factors (strengths and weaknesses), and external factors (opportunities and threats). According to Gurel (2017), SWOT analysis is an analytical tool that is often used in strategic planning and strategic management of an organization.

Turen Integrated Vocational School is a private school that is still newly established. The school is founded in 2008 with two initial majors namely motorcycle marketing and engineering (TSM), but in the course of time the TSM department is closed due to the lack of future participants' interest. The existence of this educational institution can also be in danger in the future if it does not have a powerful strategy as an anticipation effort to get more students. In addition, Turen Integrated School also needs to fix the existing weaknesses and to maintain its internal strengths. Furthermore, the school is expected to be able to see the various opportunities that exist in order to develop its educational institutions and to answer the challenges of its external environment. Thus, by looking at the school's problem, researchers are interested in conducting research by employing SWOT analysis and its implementation strategies in educational management at Turen Integrated Vocational Schools.

The purposes of this study were to analyze, to describe SWOT and to formulate an implementation strategy in educational management at Turen Integrated Vocational School. Furthermore, this study also aims to invent the right implementation strategy in maximizing the excellence or strength factor, utilizing various opportunities, minimizing weaknesesses, and overcoming various threats in education management.

\section{Literature Study}

\subsection{SWOT Analysis}

SWOT analysis is often used as an analytical tool which is utilized in a company to find the most correct strategies so that the company can achieve its objectives. According to Rangkuti (2016), SWOT analysis is a systematic 
identification of various factors to formulate a company's strategy. This analysis is based on the relationship or interaction between the internal elements (strengths and weaknesses) against the external elements (opportunities and threats). The SWOT analysis model can be considered as the most basic method of analysis, which is useful for observing a topic or problem from four different sides. In SWOT analysis, strengths and weaknesses are included within internal factors, while opportunities and threats are listed as external factors. Strengths and weaknesses are considered as the positive and the negative internal factors, while opportunities and threats are counted as the external factors (Antony, 2011).

\subsection{Strategy}

Chandler (in Fattah, 2015), defines strategy as the determination of the company's basic long-term goals, adoption of actions, and allocation of resources needed to achieve company goals. Thus, an organization should have a strategy in order to achieve the expected goals of the organization or company. A good and effective strategy will help a company and organization to allocate the resources that it already has in order to compete with other companies or organizations. The same thing is also stated by Porter (in Ponangsera, 2013). He says that strategy is a very important tool in a company or organization to achieve an excellence during competition.

\subsection{Educational Management}

Educational Management is a process of managing a collaborative effort by a group of people who are members of an educational organization. It aims to achieve the predetermined educational goals by utilizing existing resources and using management functions effectively and efficiently (Kristiawan, 2017). The function of management has actually been included in the definition of management which has been stated by the experts on above explanation. They are planning, organizing, implementing, and controlling or controlling. These functions are the basic elements which inherent in the management process. Later on, it will be used as a reference by managers or leaders in carrying out school's activities to achieve its goals in educational field.

\section{Research Methods}

This research was conducted by using the mixed methods. It was a research type that combined both qualitative and quantitative methods by providing a descriptive approach. This method was chosen by researchers since researchers conducted two different ways to gain data. In this study, the author moved from a case study that provided the qualitative data input (human perception) with the help of a questionnaire to quantitative method during data analysis. The qualitative data was processed into quantitative data by using SWOT analysis, then the results of the analysis would be concluded once again through the help of qualitative analysis description.

This research took place at the Integrated Turen Vocational School Malang which was located at Jl. Soekarno Hatta no. 2 Sananrejo-Turen Village - Malang-East Java Regency. The population in this study were all of staff teachers, school's foundation, the school's committee members. The number of the respondents employed as research participants/ sample was 5 people. They were the key informants who comprehended and understood well the development of this educational institution. The research instrument used were questionnaires and interviews as primary data sources. Next, the secondary data sources were literature study and documentation study. While data analysis in this study were using qualitative and quantitative analysis based on SWOT analysis with matrix approaches SWOT, IFAS, EFAS, and IE.

\section{Research Results \\ 4.1 Qualitative Analysis}

From the interview results conducted with research participants, the internal and external conditions of the school that could be obtained were as follows: 


\begin{tabular}{|c|c|c|}
\hline$\bigcup^{\text {Internal Factor }}$ & 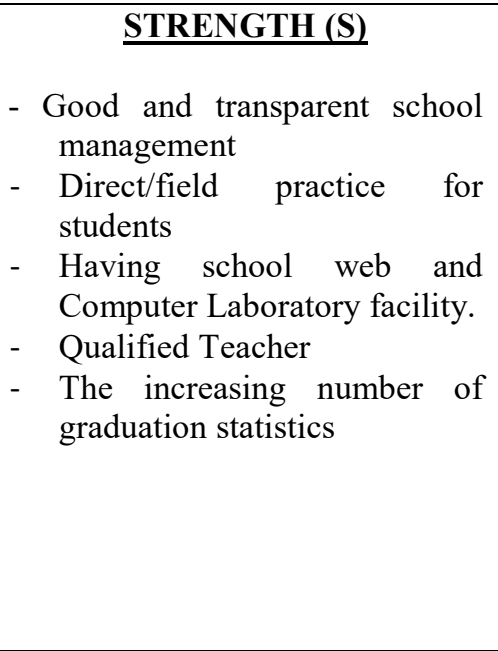 & $\begin{array}{l}\text { WEAKNESSES (W) } \\
\text { - Lack of learning facilities and practices } \\
\text { - Lack of use of social media promotion } \\
\text { - Limited and less strategic place } \\
\text { - Small payment for teacher and non- } \\
\text { permanent teacher } \\
\text { - The school's majors were similar to other } \\
\text { vocational education institutions in Turen } \\
\text { - Alumni were not well coordinated by the } \\
\text { educational institution } \\
\text { - Lack of cooperation with other companies } \\
\text { for the marketing field } \\
\text { - It had to share office's room with junior } \\
\text { high school office. } \\
\text { - Minimal quantity of teaching staffs }\end{array}$ \\
\hline $\begin{array}{l}\text { OPPORTUNITIES (O) } \\
\text { - There was a funding support } \\
\text { from the local government. } \\
\text { - Plenty of job opportunities } \\
\text { for students when they } \\
\text { graduate. } \\
\text { - A large number of alumni. } \\
\text { - The development of science } \\
\text { and technology especially } \\
\text { digital technology was very } \\
\text { helpful for educational } \\
\text { institutions for school's } \\
\text { promotion activity and it also } \\
\text { helps in changing teaching } \\
\text { and learning styles. } \\
\text { - Open a new department in } \\
\text { accordance with community } \\
\text { needs }\end{array}$ & $\begin{array}{l}\text { Strategy SO } \\
\text { (Strengths - Opportunity) } \\
\text { - Changing the style or method of } \\
\text { teaching and learning } \\
\text { - Building cooperation with } \\
\text { Marketing Companies } \\
\text { - Coordinating alumni } \\
\text { - Holding learning facilities and } \\
\text { marketing practices } \\
\text { - Working with stakeholders } \\
\text { - Open a school business } \\
\text { - Open a new department that was } \\
\text { different from other Vocational } \\
\text { High Schools in Turen and was } \\
\text { in accordance with the needs of } \\
\text { the community. }\end{array}$ & $\begin{array}{l}\text { Strategy WO } \\
\qquad \text { (Weakness - Opportunity) } \\
\text { - Developing facilities and infrastructure for } \\
\text { teaching and learning process. } \\
\text { - Opening sports fields and } \\
\text { installing sports facilities } \\
\text { - Expanding school's land } \\
\text { - Building boarding schools } \\
\text { - Bringing a school car } \\
\text { - Using technology to promote } \\
\text { - Cost optimization } \\
\text { - The optimization of organizational } \\
\text { functions of vocational education } \\
\text { institution }\end{array}$ \\
\hline $\begin{array}{l}\text { THREATS (T) } \\
\text { - There were other schools } \\
\text { around the school. } \\
\text { - The number of students was } \\
\text { decreasing. } \\
\text { - There were employees who } \\
\text { wanted to resign from the } \\
\text { school. } \\
\text { - Lack of support from the } \\
\text { environment or from village } \\
\text { officials near the school }\end{array}$ & $\begin{array}{l}\text { Strategy ST } \\
\text { (Strengths - Opportunity) } \\
\text { - Increasing the promotion of } \\
\text { educational institutions directly } \\
\text { and routinely } \\
\text { - Holding a benchmark with other } \\
\text { vocational education institutions } \\
\text { - Increasing the cooperation and } \\
\text { performance of educators and } \\
\text { asking the educators to work } \\
\text { based on the given job } \\
\text { description w } \\
\text { - Building cooperation with the } \\
\text { Village Government }\end{array}$ & 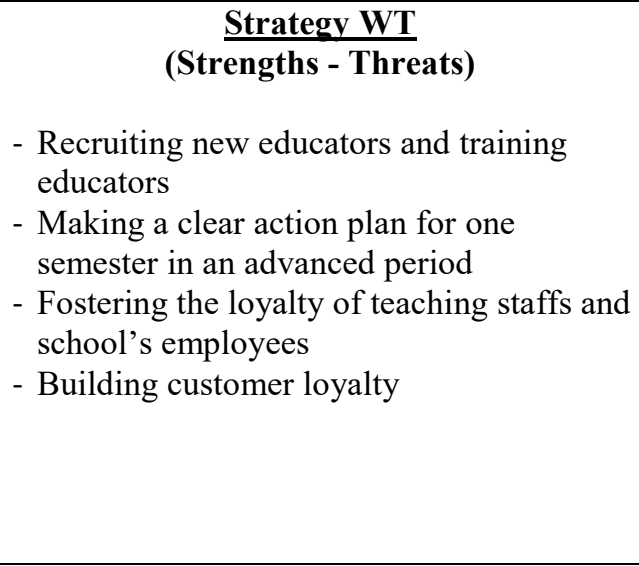 \\
\hline
\end{tabular}

\section{Table 1.1}

\section{Results of the SWOT Matrix}

Based on the SWOT matrix table, there were four strategies obtained. The formulation of the strategy was as follow: First, the SO strategy (strengths opportunities). In this strategy of formulation, the school utilized all of the strengths that it had to seize and to utilize the existing various opportunities. Second, the WO (weaknessesopportunities) strategy. The formulation of this strategy was applied based on the utilization of existing opportunities by reducing the flaws or weaknesses of educational institutions in this school. Third, the ST (strengths-threat) strategy. This strategy formulation used the strength of this educational institution to overcome the external threats of educational institutions. Fourth, the weaknesses-threat WT strategy. This weaknesses-threat formulation seek to reduce weaknesses and to stay away from the various threats that existed. 


\subsection{Quantitative Analysis}

The SWOT analysis process with quantitative methods was an analysis using the EFAS matrix approach (External Strategic Factors Analysis Summary), the IFAS (Internal Strategic Factors Analysis Summary) matrix, and the Internal-External (IE) matrix. The results of the study are described as follows:

A. IFAS Matrix

Based on the internal environmental factors, the data obtained was:

\begin{tabular}{|c|c|c|c|}
\hline Internal Strategic Factors & $\begin{array}{c}\text { Weigh } \\
t \\
\end{array}$ & $\begin{array}{c}\text { Ratin } \\
g\end{array}$ & $\begin{array}{c}\text { Weighte } \\
\text { d Score }\end{array}$ \\
\hline \multicolumn{4}{|l|}{ Strengths } \\
\hline Good and transparent school management & 0.15 & 4 & 0.6 \\
\hline Direct field practice for students & 0.07 & 3 & 0.21 \\
\hline The increase number of graduation statistics every year & 0.12 & 4 & 0.48 \\
\hline Teacher Quality & 0.15 & 4 & 0.6 \\
\hline Having a school website and adequate computer facilities & 0.07 & 4 & 0.28 \\
\hline TOTAL & 0.56 & & 2.17 \\
\hline \multicolumn{4}{|l|}{ Weaknessess } \\
\hline Inadequate learning facilities & 0.05 & 3 & 0.15 \\
\hline Minimal use of social media for school promotion & 0.03 & 2 & 0.06 \\
\hline Minimal teacher quantity & 0.05 & 2 & 0.1 \\
\hline Limited and less strategic space & 0.05 & 2 & 0.1 \\
\hline Sharing office space with junior high school's office & 0.05 & 3 & 0.15 \\
\hline Small payment for teachers and non-permanent teachers & 0.06 & 3 & 0.18 \\
\hline $\begin{array}{l}\text { Having similar department program with other vocational education institutions } \\
\text { in Turen }\end{array}$ & 0.06 & 3 & 0.18 \\
\hline Less coordinated alumni & 0.04 & 3 & 0.12 \\
\hline Lack of cooperation with companies in the marketing sector & 0.05 & 3 & 0.15 \\
\hline TOTAL & 0.44 & & 1.19 \\
\hline Total Scores & 1 & & 3.36 \\
\hline
\end{tabular}

\section{Table 1.2}

The Research Results of IFAS Factors

Based on the IFAS table above, it is known that there are 5 strength factors and 9 weakness factors possessed by Turen Integrated Vocational School. From the existing factors, the average total is 3.36 where the total strength is 2.17 and the total weakness is 1.19 .

\section{B. EFAS Matrix}

Based on external environmental factors, the data obtained are as follows:

\begin{tabular}{lccc}
\multicolumn{1}{c}{$\begin{array}{l}\text { Internal Strategic Factors } \\
\text { Opportunities }\end{array}$} & $\begin{array}{l}\text { Weigh } \\
\text { t }\end{array}$ & $\begin{array}{l}\text { Ratin } \\
\text { g }\end{array}$ & $\begin{array}{l}\text { Weighte } \\
\text { d Score }\end{array}$ \\
\hline There is a fund support from the government. & 0.12 & 4 & 0.48 \\
Plenty of job opportunities for students when they graduated from the school. & 0.15 & 3 & 0.45 \\
Big number of alumni & 0.12 & 4 & 0.48 \\
The development of Science and Technology & 0.09 & 3 & 0.27 \\
Open new departments which was in accordance with community needs. & 0.1 & 4 & 0.4 \\
TOTAL $\mathbf{O}$ & $\mathbf{0 . 5 8}$ & $\mathbf{2 . 0 8}$ \\
Threats & 0.15 & 3 & 0.45 \\
There were other schools around the school. & 0.12 & 3 & 0.36 \\
The number of students was decreasing. & 0.06 & 2 & 0.12 \\
There were employees who wanted to resign. & 0.09 & 1 & 0.09 \\
Lack of support from the environment or from village officials near the school & $\mathbf{0 . 4 2}$ & $\mathbf{1}$ & $\mathbf{1 . 0 2}$ \\
TOTAL T & $\mathbf{1}$ & $\mathbf{3 . 1}$ \\
\hline
\end{tabular}

\section{Table 1.3}

EFAS Factor Research Results

Based on the EFAS data table above, it is known that there are 5 opportunity factors and 4 threat factors. From the data, the average total is 3.1 where the total opportunity value is 2.08 and the total threat value is 1.02 .

\section{IE Matrix}

The IE (internal-external) matrix was the subsequent step of EFAS and IFES matrices which were used to determine the position of educational institutions. The position of the educational institution could be determined 
by the existence of the total score of the two matrices. The results of the values obtained are as follows:

a) The strengths score was 2.17 while the weaknesses score was 1.19 so if the strengths -weaknesses scores then the result was 0.98 . This result was placed on the $\mathrm{X}$ axis. This result illustrated a weak internal position.

b) The opportunities score was 2.08 while the threat score was 1.02 . Therefore, when opportunities - threats, the result was 1.06. This result was placed as the $\mathrm{Y}$ axis. This result showed a low external position.

The diagram position is described as follows:

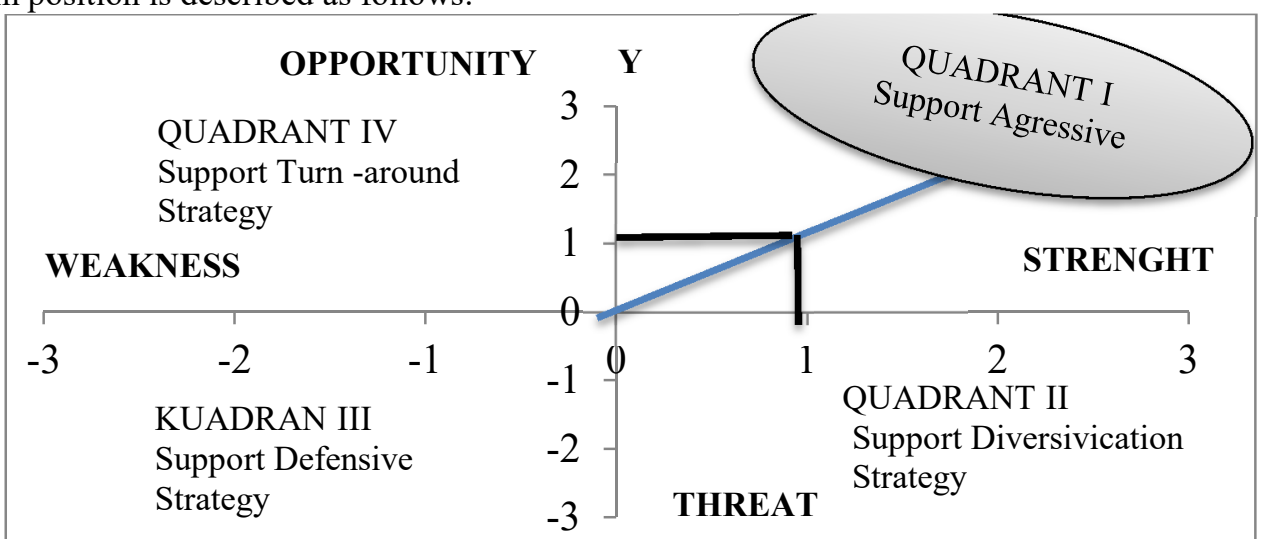

Figure1. Results of IE Matrix in a SWOT analysis

Based on the IE matrix above, it can be seen that the strategic position of the school education institution is in the "quadrant I" which supports aggressive strategies. An aggressive strategy is a strategy in which this educational institution utilizes or possesses the existing internal strengths to seek further opportunities.

\section{Discussion}

\subsection{Internal Environment Analysis}

The internal strengths of educational institutions included as follows: first, a good and transparent school management. It could be inferred that the current Turen Integrated School management was better and more transparent than on the previous years. This thing had implications for school's effectiveness and efficiency in service. Good school management included two things, namely transparency and accountability. Second, it was the number of field practicing students. This school had a program to not only equip students with knowledge but also to let students feeling the aspects of their skills or abilities. Third, Turen Integrated School had a school website and adequate computer facilities. This educational institution already owned a computer laboratory and this would ease the school, especially during the teaching and learning process, access to information, school promotion. Furthermore, the school's computer laboratory would help students to do the computer-based final exams. The fourth strength was the quality of the teacher. The quality of teachers in Turen Integrated School was very professional. The teaching staff in this school were undergraduate teachers form a number of existing universities and were assigned to teach in accordance to their expertise. Fifth, this school had good graduation statistic in every year. The graduation number reached 100 percent.

While the weaknesses possessed by this school were including as follows: First, the infrastructure was inadequate. Turen Integrated School was having lack of supporting facilities, such as the absence of a school field and sports facilities for students. On the other hand, the other rooms: teacher rooms, non-computer laboratories, computers, principals' rooms, administrative rooms, and libraries were still integrated with the Integrated Junior High School. Second, it was the lack of use of social media for promotion. Third, Turen Integrated School had a limited and less strategic school space even though it was located on the edge of a highway. Based on the school land certificate, the school area was 886 M2 (Eight Hundred Eighty Square Meters) wide. Fourth, it was using one work space with junior high school. This school was placed to be in one work unit or space with an Integrated Junior High School. This thing, of course inhibited the performance of the school employees or teachers in improving the quality of education. The fifth factor was the small payment for the permanent teachers and the nonpermanent teachers. The salary number of educators and employees at this vocational school could be classified as very low because it was under the minimum wage (UMK) of Malang Regency. Sixth, there was no public transportation that passed by in front of the school. This problem was a major obstacle for Turen Integrated School, especially when school was accepting students whose homes were located far from schools. Seven, the school had the same department programs with other schools. This made the competition was more competitive. Eighth, alumni were not well coordinated by educational institutions. Ninth, there was minimal collaboration with companies in the marketing sector.

\subsection{External Environmental Analysis}

The external factors of this school in terms of opportunities were including: First, there was support from the 
government in the form of funds. It also received educational assistance from the central and regional governments such as scholarships for students' achievements, scholarships for disadvantaged students, BOS, and others. Second, there were companies that needed Vocational High School alumni as their employee. Their field of work was related to marketing business. Third, there were many job opportunities for students when they graduate. Fourth, the number were 191 alumni that could be seen as an opportunity to build and to revive the school. Furthermore, the school could ask the help of alumni to promote itself. The fifth internal factor was the development of digital technology. The development of digital technology could be employed as an opportunity for Turen Integrated School to do school promotion, to change its teaching and learning styles, and to have an education management information system, and so on. Sixth, it was the opening of a new department/ major which was in accordance with community needs. Turen Integrated School should be able to see the future opportunities of opening a new department while at the same time it should also be able to answer the needs of the community.

While the threats from this school included the followings: First, there were other vocational institutions around the school. This made the competition between institutions was increasingly tensed. Second, the number of students was decreasing. The quantity of students which decreasing each year, made the existence of this school was in danger because students were the primary customers in educational institutions. Third, there were employees and school's staffs who wanted to resign from this educational institution.

Based on the results of the SWOT analysis, the position of this school was found in "quadrant I", which meant that the educational institution was placed in an "aggressive strategy". The aggressive strategy was a strategy used by educational institutions to see a variety of strengths $(\mathrm{S})$ in exploiting opportunities $(\mathrm{O})$ that existed. The strategy that should be applied in the current conditions of the school was by supporting an aggressive growth policy (Growth Oriented Strategy). In this strategy, the examples of concrete implementation were by changing the school's style or method of teaching and learning, building cooperation with marketing companies, coordinating alumni, providing more learning facilities, direct filed marketing practices, working together with stakeholders, opening school businesses, and opening new majors which were different from other Vocational Schools in Turen district and were in accordance with the needs of the local community.

\section{Conclusion and Suggestion}

The internal environmental conditions of Turen Integrated School have both strengths and weaknesses. The strength factors of this educational institution that can be seen are as follows: good management of the school, the teacher's ability as the basic source of resources during the teaching and learning process, the direct field practice for students, having a school web and computer laboratory, and having good academics record as an educational institution.

While the weaknesses of this educational institution include as follows: inadequate infrastructure; limited and less strategic school space; poor coordination alumni; sharing room with the Integrated Junior High School for teacher room, administrative space and the principal's room; teacher quantity; low payment for permanent and non-permanent teachers; minimal coordination with marketing companies; having only one department; having similar department as other vocational institutions; and the lack of school promotion. Both of above factors (the strengths and weaknesses factors) are the supporting and inhibiting factors for Turen Integrated School.

The external environmental conditions of Turen Integrated School have both opportunities and threats. The opportunities owned by schools could be seen in as follows: government support; companies that need vocational schools graduates especially in the field of marketing; a large number of alumni; the development of modern technology that could be maximized for promotional activities and the implementation of education information systems for institutions; the opening of new majors, and the recruitment of new teachers. While the threat factor includes the presence of other vocational institutions around the school; the decreasing number of students for every year; educators and employees who want to resign from the school; and lack of support from the village government. Furthermore, the strategy that is in line with the current school position is an aggressive strategy. This means that Turen Integrated School is better to support an aggressive growth policy (Strength oriented strategy) as its approach.

This school should maintain the advantages that it has been possessing. Thus, the internal strengths could improve the quality of schools' education and it could also help the school to be able to compete well with other schools. This is very important so that Turen Integrated School could still exist and survive in the competition. It should also improve their educational management as an institution. In order, to be able to overcome the existing weaknesses, Turen Integrated School is expected to improve its input, process and output factors. This is considered as very important because the good quality of education could only be achieved if the inputs, processes, and outputs have high quality. This school has various external opportunities in improving its input, process, and output. Thus, it is expected that the school could the available various opportunities to leverage their educational institutions so they can compete with other vocational education institutions such as by coordinating alumni, opening new departments which are fit in with wider community's need, using web schools and social media for promotion, recruiting educators, and so on. 
To bring all of the opportunities into real life, Turen Integrated School as an educational institution is advised to use their maximum power in capturing those opportunities since the existence of Turen Integrated School is currently in danger. The threats are in the form of the followings: the decreasing number of students each year; there is a number of employees and non-permanent teachers who want to resign, and the existence of other vocational education institutions around the school. By looking at the previously mentioned threats, Turen Integrated School should immediately look for and change its educational strategies by utilizing its internal strengths, minimizing weaknesses, and employing the existing opportunities so that it can exist or survive in a competition with other schools.

\section{References}

Antony, J. (2011). Reflective Practice A Swot analysis on Six Sigma: some perspectives from leading academics and practitioners. International Journal of Productivity and Performance Management, Vol. 61 No. 6.

Fattah, N. (2015). Manajemen Stratejik Berbasis Nilai (86). Bandung: PT. Remaja Rosdakarya.

Gurel, E. and Merba T. (2017). "Swot Analysis: A Theoretical Review", The Journal of International Social Research, Vol: 10 Issue: 51, 19.

Kristiawan,M.(2017)."Manajemen Pendidikan"

in https://www.researchgate.net/publication/316100289 Manajemen Pendidikan?enrichId=rgreq052c0fc83b4 daf734cfc4bc69c434f42-XXX\&enrichSource. (Accessed on Januari 10 (2019).

Ponangsera, T. (2013). "Strategi Pengembangan Kualitas Pelayanan Melalui Metode Importance Performance Analysis (Studi Empiris pada Pelanggan PT. Kimia Farma Apotek Unit Bisnis Yogyakarta)" Jurnal Bisinis Strategi, Vol. 22, No. 2, 4.

Rangkuti, F. (2016). Teknik Membedah Kasus Bisnis Analisis SWOT (19). Jakarta: PT Gramedia.

Saebani, Beni A. and H. Koko K. (2016). Filsafat Manajemen Pendidikan (22). Cet. Pertama, CV. Pustaka Setia, Bandung.

Solihin, I. (2012). Manajemen Strategik (24). Jakarta: Erlangga. 